\title{
TINJAUAN KEGIATAN PEMBERANTASAN SARANG NYAMUK (PSN) DAN INDEKS AEDES AEGYPTI INVESTATION LEVEL DI KELURAHAN PADANG SAMBIAN KAJA KECAMATAN DENPASAR BARAT TAHUN 2017
}

\author{
Ni Luh Ayu Rahma Primantari ${ }^{1}$, I Nyoman Gede Suyasa ${ }^{2}$
}

\begin{abstract}
The high cases of DHF are strongly influenced by environmental factors that include geographical and demographic conditions. These factors are very influential on the population density of Aedes Aegypti mosquitoes. The presence of larva Aedes Aegypti in a region is an indicator of the presence of Aedes Aegypti mosquito populations in the area so that it can lead to the occurrence of cases of $D H F$, therefore the eradication strategy needs to be done through mosquitoes eradication activities (PSN) by the community continuously and periodically. The purpose of this research is to know the review of Mosquito Nest (PSN) and Aedes aegypti investation level in Padang Sambian Kaja Subdistrict, West Denpasar District. The type of descriptive study with cross-sectional design. The number of samples is 97 people with random sampling method. Data collection by doing larvae and kusioner examination. Result of research got result of implementation of eradication of mosquito nest by society in sub district of Padang Sambian Kaja District of West Denpasar mostly in less category that is counted 41 person (42,3\%). The index of Aedes Aegypti Infestation Level record in Padang Sambian Kaja Village is included in the high risk of $H I=82.97 \%, C I=19.61 \%$, and $B I=$ $156.70 \%$. Suggestion to involve the community in larva examination by forming cadres jumantik so it can perform periodic larvae examination at each region.
\end{abstract}

Keywords: eradication of mosquito nest;aedes aegypti investation level. 
Lingkungan merupakan salah satu indikator yang sering kali mendapatkan perhatian khusus dalam menilai status kesehatan masyarakat maupun individu. Faktor perilaku, pelayanan kesehatan dan genetik serta lingkungan menentukan baik buruknya derajat kesehatan seseorang atau masyarakat(1). Penyakit berbasis lingkungan masih menjadi masalah kesehatan yang dihadapi masyarakat saat ini. Salah satu penyakit yang disebabkan oleh kondisi sanitasi lingkungan yang buruk adalah penyakit Demam Berdarah Dengue (DBD). Faktor lingkungan memainkan peranan bagi terjadinya wabah. Lingkungan dengan kondisi banyak air tergenang dan barang-barang yang memungkinkan air tergenang merupakan tempat ideal bagi perkembangan penyakit tersebut(2)

Faktor lingkungan tersebut sangat berpengaruh terhadap kepadatan populasi nyamuk Aedes aegypti yang dapat diukur melalui kepadatan jentik dan jumlah container. Carayang digunakan untuk menentukan distribusi kepadatan populasi, habitat utama larva, faktor resiko berdasarkan waktu dan tempat yang berkaitan dengan penyebaran dengue, dan tingkat kerentanan atau kekebalan insektisida yang dipakai, maka sangat penting untuk dilakukan indeks pencatatan Aedes aegypti atau indeks Aedes aegypti Investation Level merupakan ukuranukuran yang dipakai untuk mengetahui kepadatan jentik Aedes sp yang terdiri dari Indek rumah (house index/HI), Container Index (CI), Breteau index (BI) (3) World Health Organization (WHO) mengatakan wabah DBD sekarang telah menjadi ancaman utama bagi kesehatan masyarakat global. Lebih dari 2,5 miliar penduduk dunia berisiko terkena penyakit demam berdarah, dengan mayoritas atau $70 \%$ populasi hidup di kawasan Asia Tenggara (4). WHO tercatat negara indonesia sebagai negara dengan kasus Demam Berdarah Dengue tertinggi di Asia Tenggara (5). Menurut Kemenkes RI (4) Indonesia menempati peringkat pertama dalam jumlah kasus DBD di Asia Tenggara dengan jumlah kasus di 34 provinsi di Indonesia sebanyak 71.668 orang, dan 641 diantaranya meninggal dunia. Angka tersebut lebih rendah dibandingkan tahun sebelumnya, yakni tahun 2014 dengan jumlah penderita sebanyak 112.511 orang dan jumlah kasus meninggal sebanyak 871 penderita. Berdasarkan data dari Dinas Kesehatan Provinsi Bali tahun 2015 Insiden Rate (jumlah kasus per 100.000 penduduk) di Bali adalah 244,0, sedangkan Case Fatality Rate (angka kematian per jumlah kasus) di Bali adalah 0,275. Dari semua kabupaten/kota yang ada di Bali, angka kasus DBD tertinggi tahun 2015 di Gianyar yaitu 434,5, kedua Badung 290,1, dan Buleleng 283,5. Namun angka kematian tertinggi ada di Denpasar yaitu 0,84, kedua Buleleng 0,30, dan Gianyar 0,29(1). Empat kecamatan di wilayah kota Denpasar, Denpasar barat termasuk kecamatan dengan kasus DBD tertinggi di kota Denpasar. Penderita Demam Berdarah Dengue diketahui mengalami peningkatan cukup tinggi di Kecamatan Denpasar Barat. Dari total 477 kasus pada triwulan pertama di tahun 2015. Denpasar Barat tercatat telah terjadi kasus DBD sebanyak 168. Tingginya kasus DBD di daerah Denpasar disebabkan oleh lingkungan dengan tingkat sanitasi yang kurang memadai, tingkat kepadatan penduduk serta masih rendahnya peran masyarakat dalam pemberantasan sarang nyamuk.

1 Mahasiswa Jurusan Kesehatan Lingkungan Poltekkes Denpasar

2 Dosen Jurusan Kesehatan Lingkungan Poltekkes Denpasar 
Kesadaran dan kepedulian masyarakat dapat diwujudkan dengan peran serta masyarakat untukmelakukan upaya pencegahan penyakit demam berdarah, peran serta kepala keluarga diharapkan dapat memotivasi anggota keluarganya untuk menjaga kebersihan lingkungan, melakukan pemberantasan sarang nyamuk. Berdasarkan latar belakang diatas peneliti tertarik untuk meneliti "Tinjauan Kegiatan Pemberantasan Sarang Nyamuk (PSN) dan Indeks Aedes aegyptiInvestation Level di Kelurahan Padang Sambian Kaja Kecamatan Denpasar Barat Tahun 2017.

Tujuan penelitian ini adalah (1) untuk mengetahui kegiatan pemberantasan Sarang Nyamuk oleh masyarakat di Kelurahan Padang Sambian Kaja Kecamatan Denpasar Barat. (2) untuk mengetahui index pencatatan Aedes aegyptiInvestation Level : index pencatatan House Index (HI), Container Index (CI) dan Breteau Index (BI) di Kelurahan Padang Sambian Kaja Kecamatan Denpasar Barat.Manfaat teoritis penelitian adalah: (1) sebagai bahan informasi yang berguna untuk penelitian selanjutnyadalam mengkaji berbagai aspek yang terkait dengan bidang index pencatatan Aedes aegypti investation levels dan kegiataan PSN. (2) dapat memberikan informasi dalam memperkaya konsep dan teknis dalam mengoptimalkan kebiasaan masyarakat untuk tidak membiarkan kontainer yang berisi air dalam keadaan terbuka sehingga dapat mencegah adanya jentik nyamuk Aedes aegypti.Manfaat Praktis penelitian adalah: (1) Bagi peneliti : menambah wawasan berpikir dalam melakukan penelitian selanjutnya serta dapat menerapkan teori yang sudah diperoleh selama perkuliahan. (2) Bagi masyarakat : Hasil penelitian ini dapat dijadikan sebagai sumbangan pemikiran bagi masyarakat untuk mengoptimalkan upaya-upaya pencegahan kejadian demam berdarah dengue salah satunya adalah dengan melakukan pemberantasan vektor.

\section{METODE}

Penelitian inimengunakan jenis penelitian deskriptif. Dengan meliputi suatu objek dan menggambarkan suatu kondisi yang sebenarnya terjadi pada lokasi penelitian yang meliputi kegiatan Pemberantasan Sarang Nyamuk (PSN) dan indeks pencatatan Aedes aegypti investation level. Penelitian ini dilakukan di Kelurahan Padang Sambian Kaja, Kecamatan Denpasar Barat. Tempat ini dipilih sebagai tempat penelitian karena merupakan wilayah yang mempunyai angka kejadian DBD tertinggi dan sebelumnya belum pernah dilakukan penelitian mengenai tinjauan kegiataan Pemberantasan Sarang Nyamuk (PSN) dan indeks pencatatanAedes aegypti investation level. Populasi dalam penelitian ini adalah semua kepala keluarga (KK) di Kelurahan Padang Sambian Kaja, Kecamatan Denpasar Barat sebanyak 3264 KK. Besar sampel sebanyak 97 KK. Teknik pengambilan sampel yang digunakan dalam penelitian ini adalah random sampling yaitu teknik pengambilan sampel yang dipilih secara acak atau setiap unsur populasi harus memiliki kesempatan yang sama untuk bisa dipilih menjadi sampel. Pengumpulan data menggunakan lembar observasi berupa formulir pemeriksaan survei jentik yang akan diamati oleh peneliti dan kuesioner kegiatan PSN yang akan diisi oleh responden.Alat pengumpul data atau instrumen yang digunakan dalam penelitian ini adalah formulir survei 
jentik nyamuk dan Kuesioner untuk sarang nyamuk. Pengamatan jentik mengetahui pelaksanaan pemberantasan dilakukan dalam rumah dan luar rumah

\section{HASIL DAN PEMBAHASAN}

Tabel 1

Distribusi Responden Berdasarkan Umur di di Kelurahan Padang Sambian Kaja, Kecamatan Denpasar Barat Tahun 2017

\begin{tabular}{llcc}
\hline No & Umur & \multicolumn{2}{c}{ Hasil Penelitian } \\
& & Frekuensi & Persentase \\
\hline 1 & $20-30$ tahun (Dewasa muda) & 22 & 22.7 \\
2 & $31-40$ tahun (dewasa madya) & 31 & 32.0 \\
3 & $41-50$ tahun (Dewasa akhir) & 29 & 29.9 \\
4 & $51-60$ tahun (Awal lansia) & 15 & 15.5 \\
\hline & Total & 97 & 100,0
\end{tabular}

Berdasarkan tabel 1 menunjukkan bahwa karakteristik responden berdasarkan umur menurut Depkes RI, 2009(6) dikategorikan berdasarkan umur dewasa sebagian besar berumur 31-40 tahun yaitu sebanyak 31 orang (32\%).

Tabel 2

Distribusi Responden Berdasarkan Pendidikan di di Kelurahan Padang Sambian Kaja, Kecamatan Denpasar Barat Tahun 2017

\begin{tabular}{llcc}
\hline No & Pendidikan & \multicolumn{2}{c}{ Hasil Penelitian } \\
& & Frekuensi & Persentase \\
\hline 1 & SD & 27 & 27.9 \\
2 & SMP & 40 & 41.2 \\
3 & SMA & 30 & 30.9 \\
\hline & Total & 97 & 100,0
\end{tabular}

Berdasarkan tabel 2 menunjukkan bahwa karakteristik responden berdasarkan pendidikan sebagian besar tamat SMP yaitu sebanyak 40 orang $(41,2 \%)$.

Tabel 3

Distribusi Frekuensi Kegiatan Pemberantasan Sarang Nyamuk di Kelurahan Padang Sambian Kaja, Kecamatan Denpasar Barat Tahun 2017 
Jurnal Kesehatan Lingkungan Vol.8 No.1 Mei 2018: 1 - 8

\begin{tabular}{clccc}
\hline No & Pemberantasan Sarang Nyamuk & \multicolumn{2}{c}{ Hasil Penelitian } \\
& & Frekuensi & Persentase \\
\hline 1 & Baik & 33 & 34.0 \\
2 & Cukup & 23 & 23.7 \\
3 & Kurang & 41 & 42.3 \\
\hline & & 97 & 100,0 \\
\hline
\end{tabular}

Berdasarkan tabel 3 menunjukkan bahwa kegiatan pemberantasan sarang nyamuk sebagian besar dalam kategori kurang yaitu sebanyak 41 orang $(42,3 \%)$.

Tabel 4

Distribusi Frekuensi Indeks Pencatatan Aedes aegyptiInvestation Level di

Kelurahan Padang Sambian Kaja, Kecamatan Denpasar Barat Tahun 2017

\begin{tabular}{clc}
\hline No & \multicolumn{1}{c}{ Uraian } & Indek \\
\hline 1 & House index & $82,87 \%$ \\
2 & Container index & $19,61 \%$ \\
3 & Breteau index & $156,70 \%$ \\
\hline
\end{tabular}

Berdasarkan tabel 4 menunjukkan bahwa ketiga indek Aedes aegypti Investation Level di Kelurahan Padang Sambian Kaja termasuk ke dalam resiko tinggi yaitu HI $=82,97 \%, \mathrm{CI}=19,61 \%$, dan $\mathrm{BI}=156,70 \%$.

\section{Kegiatan pemberantasan sarang nyamuk}

Hasil penelitian menunjukkan bahwa pemberantasan sarang nyamuk sebagian besar dalam kategori kurang yaitu sebanyak 41 orang $(42,3 \%)$. Hasil penelitian ini juga didukung oleh penelitian sebelumnya yang dilakukan oleh(7) tentang hubungan tindakan pemberantasan sarang nyamuk dengan keberadaan larva vektor DBD di kelurahan lubuk buaya. Hasil penelitian menunjukkan sebanyak 57 responden $(51,82 \%)$ memiliki tindakan PSN kurang baik.

Hasil penelitian yang didapat didukung oleh teori(8) keterlibatan masyarakat dalam pencegahan penyakit DBD sangatlah diperlukan karena sangat mustahil dapat memutus rantai penularan jika masyarakat tidak terlibat sama sekali. Peran serta masyarakat ini dapat berwujud pelaksanaan kegiatan $3 \mathrm{M}$ plus menutup wadah-wadah penampungan air, mengubur atau membakar barang-barang bekas yang menjadi sarang nyamuk, dan menguras atau mengganti air di tempat tampungan air) di sekitar rumah dan melaksanakan pemberantasan sarang nyamuk pada lingkungannya serta melakukan tindakan plus seperti menggunakan kelambu saat tidur, memasang kasa, memelihara ikan pemakan vektor

1 Mahasiswa Jurusan Kesehatan Lingkungan Poltekkes Denpasar

2 Dosen Jurusan Kesehatan Lingkungan Poltekkes Denpasar 
nyamuk, menggunakan obat nyamuk oles/ repellant, menggunakan bubuk abate, memeriksa jentik nyamuk secara berkala serta tindakan lain yang sesuai dengan kondisi setempat.

Berdasarkan hasil penelitian banyak responden yang belum melaksanakan PSN DBD secara kimia dan biologi. Cara ini memang belum banyak dapat dilakukan oleh responden. Secara kimia PSN DBD biasanya dilakukan dengan menaburkan bubuk abate pada tempattempat penampungan air, akan tetapi bubuk abate belum bisa didapatkan secara mudah sehingga responden belum dapat melakukan PSN DBD secara kimia. Hal ini tentunya juga dapat menambah resiko bagi jentik nyamuk Aedes aegypti untuk hidup dan berkembangbiak pada tempat-tempat penampungan air. PSN DBD secara biologi yang dilakukan dengan cara memelihara ikan pada tempat-tempat penampungan air juga belum dilakukan responden. Sebenarnya cara ini adalah cara alamiah dan cara yang cukup efektif untuk membasmi jentik Aedesaegypti, akan tetapi responden enggan melaksanakannya karena ikan yang dipelihara akan menyebabkan bau amis pada tempat penampungan air responden.

Kegiatan pemberantasan sarang nyamuk dalam pemberantasan sarang nyamuk demam berdarah dengue di Kelurahan Padang Sambian Kaja belum terwujud secara optimal, oleh karena masih ditemukan sampah-sampah yang dibuang sembarangan/berserakan di halaman rumah dan di lingkungan pemukiman seperti: kaleng-kaleng bekas, ban-ban bekas, tempurung, serta masih ditemukannya tempat-tempat perindukan dan perkembangbiakan nyamuk demam berdarah dengue di dalam dan di luar rumah, yang kesemuanya ini dapat merupakan faktor penyebab masih tingginya kasus penyakit demam berdarah dengue.

\section{Indeks pencatatan Aedes aegyptiinvestation level}

Indeks pencatatan Aedes aegyptiinvestation level merupakan ukuran yang digunakan untuk mengetahui kepadatan jentik nyamukAedes aegypti yaitu House Index, Container Index dan Breteau Index. Kepadatan jentik nyamukAedes aegypti di Kelurahan Padang Sambian Kaja dapat dilihat dari data House IndexHasil penelitian observasi dan survei langsung jentik nyamuk dapat diketahui index pencatatan House Index (HI) Aedes aegypti Investation Level di di Kelurahan Padang Sambian Kaja termasuk ke dalam resiko tinggi yaitu $\mathrm{HI}$ $=82,47 \%$. Hasil index pencatatan House Index (HI) Aedes aegypti Investation Level di Kelurahan Padang Sambian Kaja termasuk ke dalam resiko tinggi, hasil ini didukung oleh hasil penelitian rumah yang positif jentik menunjukkan bahwa sebanyak 80 rumah responden positif jentik.

Hasil penelitian ini didukung teori WHO,2015(3) faktor kepadatan jentik dapat mempengaruhi Insidens Rate DBD terkait dengan perkembangan hidup nyamuk penular DBD dan juga dalam penularannya. Kepadatan jentik dalam rumah dipengaruhi oleh faktor lingkungan yang terdiri dari suhu udara, kelembaban udara, dan sebagainya akan mempengaruhi perkembangan hidup nyamuk. Dengan kondisi lingkungan yang sesuai nyamuk akan berkembang biak secara optimal. Perkembangan hidup nyamuk yang optimal dapat meningkatkan kepadatan jentik nyamuk. Tingginya kepadatan jentik nyamuk dan didukung dengan kepadatan penduduk 
yang tinggi akan memperbesar peluang penularan DBD sehingga akan meningkatkan Insidens Rate DBD. Hal ini sesuai dengan pengamatan peneliti saat melakukan survey nyamuk, kondisi perumahan di Kelurahan Padang Sambian Kaja yang padat dan penduduknya banyak yang menggunakan lebih dari satu TPA, secara teoritis kondisi yang seperti sangat potensial untuk tempat perindukan nyamuk Aedes aegypti.

Hasil penelitian observasi dan survei langsung jentik nyamuk dapat diketahui index pencatatan Container Index (CI) Aedes aegypti Investation Level di Kelurahan Padang Sambian Kaja termasuk ke dalam resiko tinggi yaitu $\mathrm{CI}=19,61 \%$. Pengamatan yang peneliti lakukan terhadap TPA di Kelurahan Padang Sambian Kajabahwa jenis TPA yang paling banyak positif jentik adalah got/saluran air dan bak kamar mandi, keberadaan got paling banyak positik nyamuk karena posisi got merupakan tempat yang terbuka dan gelap karena terlindung dari sinar matahari, got yang positif jentik juga tidak berhubungan langsung dengan tanah karena dibawahnya disemen, kondisi yang got jarang dibersihkan, serta tidak pernah diberikan abate sehingga hal tersebut sangat memdukung berkembangbiaknya jentik nyamuk.

Hasil penelitian observasi dan survei langsung jentik nyamuk dapat diketahui index pencatatan Breteau index (BI) Aedes aegypti Investation Level di Kelurahan Padang Sambian Kaja termasuk ke dalam resiko tinggi yaitu BI $=156,70 \%$. Menurut Depkes RI, 2014(8) keberadaan jentik Aedes sp disuatu daerah merupakan indikator terdapatnya populasi nyamuk Aedes sp di daerah tersebut sehingga dapat mengakibatkan terjadinya kasus DBD oleh sebab itu perlu dilakukan pemberantasan nyamuk Aedes $s p$ terutama pada jentiknya. Upaya mencegah berkembangnya nyamuk Aedes aegypti serta mencegah penyakit demam berdarah diperlukan upaya baik dari pemerintah melalui puskesmas dan masyarakat dalam menjaga kebersihan lingkungan. peran puskesmas sangat diperlukan seperti meningkatkan pelaksanaan pemantauan jentik rutin atau memberikan penyuluhan agar maayarakat tahu pentingnya pemberantasan sarang nyamuk secara rutin untuk menghambat perkembangbiakkan jentik nyamuk serta pembagian larvasida pada saat penyuluhan khususnya kepada masyarakat yang ditemukan jentik pada saat pemeriksaan berkala, serta bekerjasama dengan masyarakat dengan memaksimalkan kinerja pokja desa siaga terutama berkoordinasi dengan bidang Pencegahan Penyakit Menular (P2M) dengan melakukan survei jentik secara berkala/Pemeriksaan Jentik Rutin (PJR).

\section{SIMPULAN}

Kegiatan pemberantasan Sarang Nyamuk oleh masyarakat di Kelurahan Padang Sambian Kaja Kecamatan Denpasar Barat dalam kategori baik yaitu sebanyak 33 orang $(34,0 \%)$, kategori cukup yaitu sebanyak 23 orang $(23,7 \%)$ dan kategori kurang yaitu sebanyak 41 orang (42,3\%). Indeks pencatatan Aedes aegypti Investation Level di Kelurahan Padang Sambian Kaja termasuk kedalam resiko tinggi yaitu $\mathrm{HI}=82,97 \%, \mathrm{CI}=19,61 \%$, dan BI $=156,70 \%$.

\section{SARAN}


1. Bagi Puskesmas : melakukan penyuluhan dan pembagian larvasida pada saat penyuluhan khususnya kepada masyarakat yang ditemukan jentik pada saat pemeriksaan berkala, serta bekerjasama dengan masyarakat dengan memaksimalkan kinerja pokja desa siaga terutama berkoordinasi dengan bidang Pencegahan Penyakit Menular (P2M) dengan melakukan survei jentik secara berkala/Pemeriksaan Jentik Rutin (PJR).

2. Bagi Masyarakat : Melaksanakan kegiatan pemberantasan sarang nyamuk demam berdarah dengue secara terus-menerus, menggunakan metode 3M seperti menguras TPA seperti bak mandi, drum, tempayan dan lain-lain secara terus menerus, menutup tempat penampungan air seperti drum dan tempayan serta mengubur atau membuang barangbarang bekas yang tidak digunakan lagi yang dapat menampung air.

3. Bagi Peneliti Selanjutnya : dapat dijadikan bahan tambahan referensi dan bahan masukan untuk penelitian selanjutnya yang terkait dengan penelitian ini. Melakukan pemeriksaan pada tempat perindukan alami nyamuk Aedes aegypti yang memungkinkansebagai tempat bertelur dan berkembangbiak apabila penelitian dilakukan pada saat musim hujan.

\section{DAFTAR PUSTAKA}

1. Bali DKP. Profil Kesehatan Propinsi Bali Tahun. Bali; 2015.

2. Lestari K. Epidemiologi dan Pencegahan Demam Berdarah Dengue di Indonesia. 2007.

3. WHO. Guedalines For Dengue Surveillance and Mosquito control. 2015.

4. RI K. Bulitin jendela epidimiologi demam berdarah dengue. 2015;

5. Putri A. Hubungan Pengetahuan dan Sikap Masyarakat tentang Penyakit Demam Berdarah Dengue Dengan Pencegahan Vektor di kelurahan Malalayang Barat Kota Manado. 2014.

6. RI D. Kategori Umur Menurut Depkes. 2009.

7. Azlina A. Hubungan Tindak Pemberantasan Sarang Nyamuk dengan Keberadaan Larva Vektor DBD di Kelurahan Lubuk Buaya. 2014.

8. RI D. Pedoman Survai Entomologi Demam Berdarah Dengue. 2014. 